\title{
Comparing the Effect of Plant Growth Regulators on Callus and Somatic Embryogenesis Induction in Four Elite Theobroma cacao L. Genotypes
}

\author{
Modeste Kan Kouassi ${ }^{1}$ \\ Laboratoire Central de Biotechnologies (LCB), Centre National de \\ Recherche Agronomique (CNRA), KM 17 Route de Dabou, 01 BP 1740 \\ Abidjan 01, Côte d'Ivoire
}

Jane Kahia and Christophe N'guessan Kouame

Côte d'Ivoire Country Program, World Agroforestry Center (ICRAF), Cocody Mermoz, 08 BP 2823 Abidjan, Côte d'Ivoire

Mathias Gnion Tahi

Programme Cacao, Centre National de Recherche Agronomique (CNRA), Station de Recherche de Divo, BP 808 Divo, Côte d'Ivoire

\section{Edmond Kouablan Koffi}

Laboratoire Central de Biotechnologies (LCB), Centre National de Recherche Agronomique (CNRA), Côte d'Ivoire, KM 17 Route de Dabou, 01 BP 1740 Abidjan 01

Additional index words. auxin, cytokinin, petal, staminode, Theobroma cacao

\begin{abstract}
The effect of plant growth regulators on callus and somatic embryogenesis induction in four Cocoa (Theobroma cacao) genotypes was studied. Flower explants were harvested early in the morning and cultured on Driver and Kuniyuki Walnut (DKW) medium supplemented with $1 \mathrm{mg} \cdot \mathrm{L}^{-1}$ of five auxins type $(2,4$ dichlorophenoxyacetic acid (2,4-D), 3,4 dichlorophenoxyacetic acid (3,4-D), 2,4,5 trichlorophenoxyacetic acid $(2,4,5-T)$, 4-amino-3,5,6-trichloropicolinic acid (picloram), and 3,6-dichloro-2-methoxybenzoic acid (dicamba) in combination with 0.25 or $0.5 \mathrm{mg} \cdot \mathrm{L}^{-1}$ of two cytokinins type (benzylaminopurine (BAP) and 6-furfurylaminopurine [kinetin (Kin)] in a factorial experiment. The plant growth regulators $2,4-\mathrm{D}$ and $2,4,5-\mathrm{T}$ proved to have a broad spectrum action on somatic embryogenesis induction compared with 3,4-D or picloram. There were no significant differences between the two concentrations of cytokinins. However, Kin was found to be more effective in promoting somatic embryogenesis than BAP. Combining $1 \mathrm{mg} \cdot \mathrm{L}^{-1} 2,4,5-\mathrm{T}$ or $2,4-\mathrm{D}$ with $0.25 \mathrm{mg} \cdot \mathrm{L}^{-1} \mathrm{Kin}$ had a broad spectrum action on embryogenesis induction. On the other hand, combining $\mathbf{m g} \cdot \mathrm{L}^{-1}$ picloram with $0.5 \mathrm{mg} \cdot \mathrm{L}^{-1} \mathrm{Kin}$ or $1 \mathrm{mg} \cdot \mathrm{L}^{-1} 3,4-\mathrm{D}$ with $0.25 \mathrm{mg} \cdot \mathrm{L}^{-1} \mathrm{Kin}$ was only able to induce somatic embryogenesis in a few of the genotypes evaluated. The protocol developed during the current study differs from earleir works as the callus (derived from explants cultured on DKW media) was taken directly to embryo development media as opposed to earlier works in which the callus was taken through a secondary media before being transferred to an embryo development media.
\end{abstract}

Cocoa (T. cacao) is a neotropical, small, evergreen tree and native to the undergrowth of the Amazon forest (South America), and belongs to the Malvaceae family. It is cultivated around the world, for its seeds mainly used in the manufacture of chocolate and

\footnotetext{
Received for publication 23 June 2016. Accepted for publication 20 Oct. 2016 .

We would like to thank Mangara Touré Mah and Bah Grou Edwige for their technical assistance. The funds for this work were graciously donated by Mars incorporated and National Centre of Agronomic Research (CNRA) of Côte d'Ivoire.

${ }^{1}$ Corresponding author. E-mail: kanmodestekouassi@ gmail.com
}

cosmetics. Côte d'ivoire is the world's leading cocoa producer accounting for more than a third of the global supply. Cocoa plays a key role in the economy of the country contributing to $15 \%$ of its GDP, $40 \%$ of its exports, and supporting more than 6 million people (Conseil Café Cacao, 2014; ICCO, 2012). Theobroma cacao is generally a heterozygous plant with a high variability for agronomic and quality traits. Seed propagation, while efficient, is problematic, since many of the trees are unproductive. The number of planting materials produced by rooted cuttings and grafting are unbalanced and far below the quantity needed to supply farmer's demand. Therefore, there is a need to accelerate the production of the elite cocoa planting materials by using alternative methods such somatic embryogenesis. Somatic embryo production and plantlet regeneration have been achieved in a large number of genotypes ( $\mathrm{Li}$ et al., 1998; Maximova et al., 2002).

Despite the current progress in this area, the reported efficiencies of somatic embryogenesis and plant regeneration obtained remain low. Furthermore, the practical utilization of this technology for clonal propagation remains hindered by an inability to induce somatic embryogenesis from a majority of elite cocoa genotypes. For these applications to be technically and economically feasible, it is essential to optimize the system variables to obtain high multiplication rates of quality somatic embryos. This is in view of the fact that different cocoa genotypes react differently to different callus-inducing hormones (Traore and Guiltinan, 2006). Plant growth regulators play a key role by intervening in the reactions that lead to a reorientation of the program of gene expression. This expression can lead either to an unorganized growth of the cells (callus) without embryogenesis or to a polarized growth leading to a somatic embryogenesis (Dudits et al., 1995).

In T. cacao, $\mathrm{Li}$ et al. (1998) added $18 \mu \mathrm{M}$ 2,4-D and $45.4 \mathrm{~nm}$ thidiazuron in DKW medium basal salts (Driver and Kuniyuki, 1984) while López-Baez et al. (2000) used 2,4-D or $2,4,5-\mathrm{T}\left(1 \mathrm{mg} \cdot \mathrm{L}^{-1}\right)$ and $\mathrm{Kin}$ or 2 Isopentyladenine (2-ip) $\left(0.25 \mathrm{mg} \cdot \mathrm{L}^{-1}\right)$ in a modified Murashige and Skoog (MS) salts (Murashige and Skoog, 1962). These two systems resulted in somatic embryos production but some differences in efficiencies were apparent. The DKW basal salts media appears to be superior to MS media for cocoa tissue culture and although modifications of MS have given adequate results, most laboratories have switched to DKW based media (Guiltinan and Maximova, 2000). Although the different combinations have been reported to enhance somatic embryogenesis efficiency, it remains evident that different clones vary in their response given to carbohydrate sources, plant growth regulators, or basal media (Guiltinan and Maximova, 2000).

The present study was aimed at improving the induction of $T$. cacao somatic embryogenesis by combining several auxins and cytokinins. To the best of our knowledge, 3,4-D and dicamba have never been evaluated for induction of somatic embryogenesis of T. cacao.

\section{Materials and Methods}

Explants preparation. Flower buds about 4 to $5 \mathrm{~mm}$ long were collected (early in the morning before $9 \mathrm{AM}$ ) in May 2014 from four elite genotypes coded C1, C9, C14, and C16 from Center National de Recherche Agronomique experimental farm in Divo (Côte d'Ivoire). The flower buds were surfacesterilized by using $1 \%(\mathrm{w} / \mathrm{v})$ calcium hypochlorite for $20 \mathrm{~min}$ under the laminar flow cabinet. They were then rinsed four times in sterile distilled water and afterward sliced perpendicular to their longitudinal axis using 


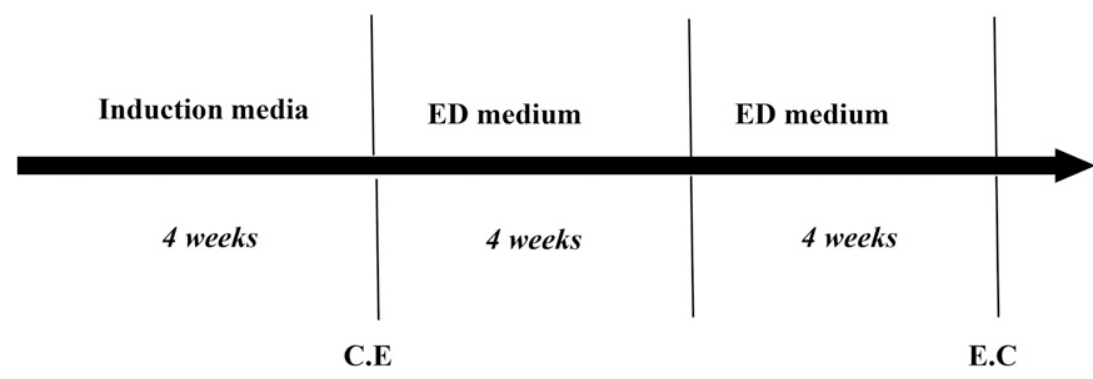

Fig. 1. Steps, time duration, and type of media used to induce embryogenic calli in four cocoa genotypes $\mathrm{ED}=$ embryo development; C.E = callogenic explants assessment; E.C = embryogenic calli assessment.

Table 1. Summary table for the percentage of callogenic explants (petal and staminode) of four cocoa genotypes on induction medium supplemented with auxins and cytokinins in a $4 \times 5 \times 4$ factorial experiment.

\begin{tabular}{|c|c|c|c|c|c|}
\hline \multirow[b]{2}{*}{ Source of variation } & \multirow[b]{2}{*}{ DF } & \multicolumn{2}{|c|}{ Petals } & \multicolumn{2}{|c|}{ Staminodes } \\
\hline & & MS & $P$ value & MS & $P$ value \\
\hline Clone & 3 & 3.49 & $<0.001$ & 17.04 & $<0.001$ \\
\hline Auxin & 4 & 10.84 & $<0.001$ & 17.00 & $<0.001$ \\
\hline Cytokinin & 3 & 3.47 & $<0.001$ & 1.22 & 0.003 \\
\hline Clone $\times$ auxin & 12 & 0.83 & 0.131 & 0.42 & 0.008 \\
\hline Clone $\times$ cytokinin & 9 & 0.88 & 0.123 & 2.29 & $<0.001$ \\
\hline Auxin $\times$ cytokinin & 12 & 2.14 & $<0.001$ & 1.45 & $<0.001$ \\
\hline Clone $\times$ auxin $\times$ cytokinin & 36 & 1.22 & $<0.001$ & 0.96 & $<0.001$ \\
\hline Residual & 163 & 0.56 & & 0.26 & \\
\hline
\end{tabular}

$\mathrm{DF}=$ degrees of freedom; $\mathrm{MS}=$ mean square.

Table 2. Effects of auxins and genotypes on callogenic explant induction in cocoa. Observations were made after 4 weeks of culture.

\begin{tabular}{lccc}
\hline & & \multicolumn{2}{c}{ Avg percentage of callogenic explants \pm SE } \\
\cline { 3 - 4 } Factor & Levels of factors & \multicolumn{1}{c}{ Petals } & Staminodes \\
\hline Auxin & $2,4-\mathrm{D}$ & $88.67 \pm 2.77 \mathrm{ab}$ & $76.14 \pm 3.54 \mathrm{ab}$ \\
& $2,4,5-\mathrm{T}$ & $87.63 \pm 2.94 \mathrm{ab}$ & $81.38 \pm 3.72 \mathrm{a}$ \\
& $3,4-\mathrm{D}$ & $63.13 \pm 2.88 \mathrm{a}$ & $80.61 \pm 3.68 \mathrm{a}$ \\
& Dicamba & $85.93 \pm 2.80 \mathrm{ab}$ & $45.97 \pm 7.27 \mathrm{c}$ \\
Genotype & Picloram & $81.42 \pm 2.57 \mathrm{ab}$ & $74.09 \pm 3.57 \mathrm{ab}$ \\
& C1 & $82.56 \pm 3.17 \mathrm{ab}$ & $38.71 \pm 3.27 \mathrm{c}$ \\
& C9 & $84.70 \pm 3.22 \mathrm{ab}$ & $76.85 \pm 4.04 \mathrm{~b}$ \\
& C14 & $91.09 \pm 2.94 \mathrm{a}$ & $85.91 \pm 4.10 \mathrm{ab}$ \\
& C16 & $91.85 \pm 3.71 \mathrm{a}$ \\
\hline
\end{tabular}

2,4-D $=2,4$ dichlorophenoxyacetic acid; $2,4,5-\mathrm{T}=2,4,5$ trichlorophenoxyacetic acid; 3,4-D $=3,4$ dichlorophenoxyacetic acid.

Values are mean \pm SE. Values in each column of explant followed by the same letter do not differ statistically at $P<0.05$ according to Duncan's test.

Table 3. Summary table for the percentage of embryogenic calli (from petal and staminode explants) of four cocoa genotypes on induction medium supplemented with auxins and cytokinins in a $4 \times 5 \times 4$ factorial experiment.

\begin{tabular}{|c|c|c|c|c|c|}
\hline \multirow[b]{2}{*}{ Source of variation } & \multirow[b]{2}{*}{ DF } & \multicolumn{2}{|c|}{ Petals } & \multicolumn{2}{|c|}{ Staminode } \\
\hline & & $\mathrm{MS}$ & $P$ value & $\mathrm{MS}$ & $P$ value \\
\hline Genotype & 3 & 4.79 & $<0.001$ & 1.93 & 0.04 \\
\hline Auxin & 4 & 5.85 & $<0.001$ & 1.42 & 0.02 \\
\hline Cytokinin & 3 & 5.01 & $<0.001$ & 0.41 & 0.67 \\
\hline Genotype $\times$ auxin & 12 & 2.02 & $<0.001$ & 2.50 & $<0.001$ \\
\hline Genotype $\times$ cytokinin & 9 & 1.87 & 0.001 & 1.33 & 0.09 \\
\hline Auxin $\times$ cytokinin & 12 & 1.39 & 0.007 & 0.97 & 0.27 \\
\hline Genotype $\times$ auxin $\times$ cytokinin & 36 & 1.03 & 0.008 & 1.20 & 0.04 \\
\hline Residual & 163 & 0.58 & & 0.79 & \\
\hline
\end{tabular}

$\mathrm{DF}=$ degrees of freedom; $\mathrm{MS}=$ mean square.

a sterile scalpel blade. The staminodes and petals were extracted using a sharp sterile forceps and used as explants.

Media formulation and culture conditions. The DKW-based medium (Li et al., 1998) was supplemented with $1 \mathrm{mg} \cdot \mathrm{L}^{-1}$ of 2,4-D,3,4-D, was adjusted to 5.7 using $0.1 \mathrm{M} \mathrm{HCl}$ or $0.1 \mathrm{M}$ $\mathrm{NaOH}$ and the media was solidified with $0.2 \%$ (w/v) phytagel. The media was autoclaved at $1.06 \mathrm{~kg} \cdot \mathrm{cm}^{-2}$ and $121{ }^{\circ} \mathrm{C}$ for $20 \mathrm{~min}$.

The explants were cultured on media under evaluation (induction media) and incubated in a dark room maintained at $25 \pm$ $2{ }^{\circ} \mathrm{C}$. After 4 weeks on induction medium, explants were transferred onto embryos development (ED) medium which is a DKWbased medium without growth regulators (Li et al., 1998). Four weeks later, a subculture was performed on fresh ED medium (Fig. 1).

Parameters evaluated. Four weeks after induction, the percentage of callogenic explants [(number of explants producing one or more calli/total number of explants $) \times 100]$ was evaluated. Twelve weeks after induction, the percentage of embryogenic calli [number of explants producing one or more embryos/ total number of calli forming explants $) \times 100]$ was evaluated on ED medium.

Experimental design and data analysis. The experiment was laid out as factorial using a completely randomized design with four factors. Auxins were considered as first factor (five levels), cytokinin concentration as second factor (four levels), genotype as third factor (with four levels), and explants as fourth factor (two levels). Thus there was a total of 160 treatments with seven replicates per treatment. The explants used for the replication were from the same batch of flowers.

The experimental unit consisting of a petri dish with each containing 15 petals and 15 staminodes was considered as a replicate. With this experimental design it was possible to evaluate from an interaction auxin/cytokinin the effect of a particular auxin on the induction of callus and somatic embryogenesis when considering all the genotypes. On the other hand, the effect of each concentration of cytokinin in the induction of somatic embryogenesis could also be evaluated. It was also possible to assess the interaction of auxin and cytokinin in the induction of callus and somatic embryogenesis from each type of explant (petal or staminode).

Xlstat 2014 was used for data analysis. Analysis of variance was performed where applicable and differences between means determined by a Duncan's test. The tests were considered as significant with $P<0.05$.

\section{Results}

Induction of callogenic explants. Depending on the explants, there was a slight difference in the effect of the factors auxin, cytokinin, and genotype on the induction of callus. With the petals, each factor and the interactions auxin $\times$ cytokinin and genotype $\times$ auxin $\times$ cytokinin had a high significant effect $(P<0.001)$ on the induction of callus. With staminodes, each factor and the interactions between the factors had a significant effect (Table 1).

Petal explants cultured on induction media supplemented with 3,4-D produced the highest percentage of explants with callus although it was not significantly different 
Table 4. Effects of auxins, cytokinins, and genotypes on embryogenic calli induction in cocoa.

\begin{tabular}{llcr}
\hline & & \multicolumn{2}{c}{ Avg percentage of embryogenic calli $\pm \mathrm{SE}$} \\
\cline { 2 - 4 } Factor & Levels of factors & Petals & Staminodes \\
\hline Auxin $\left(1 \mathrm{mg} \cdot \mathrm{L}^{-1}\right)$ & $2,4-\mathrm{D}$ & $12.06 \pm 2.00 \mathrm{a}$ & $3.36 \pm 0.77 \mathrm{a}$ \\
& $2,4,5-\mathrm{T}$ & $11.25 \pm 2.10 \mathrm{a}$ & $3.88 \pm 0.92 \mathrm{a}$ \\
& $3,4-\mathrm{D}$ & $5.14 \pm 2.09 \mathrm{~b}$ & $2.08 \pm 0.41 \mathrm{a}$ \\
& Dicamba & $0 \mathrm{~d}$ & $0 \mathrm{c}$ \\
Cytokinin concentration & Picloram & $2.99 \pm 0.52 \mathrm{c}$ & $1.186 \pm 0.28 \mathrm{bc}$ \\
& $0.25 \mathrm{mg} \cdot \mathrm{L}^{-1} \mathrm{BAP}$ & $4.95 \pm 1.46 \mathrm{~b}$ & $2.24 \pm 0.75 \mathrm{a}$ \\
& $0.50 \mathrm{mg} \cdot \mathrm{L}^{-1} \mathrm{BAP}$ & $1.71 \pm 0.61 \mathrm{bc}$ & $1.0 \pm 0.57 \mathrm{a}$ \\
Genotype & $0.25 \mathrm{mg} \cdot \mathrm{L}^{-1} \mathrm{Kin}$ & $12.34 \pm 2.04 \mathrm{a}$ & $2.03 \pm 0.75 \mathrm{a}$ \\
& $0.50 \mathrm{mg} \cdot \mathrm{L}^{-1} \mathrm{Kin}$ & $11.12 \pm 2.12 \mathrm{a}$ & $2.32 \pm 0.78 \mathrm{a}$ \\
& $\mathrm{C} 1$ & $11.40 \pm 1.97 \mathrm{a}$ & $2.12 \pm 0.77 \mathrm{c}$ \\
& $\mathrm{C} 14$ & $2.47 \pm 0.81 \mathrm{~b}$ & $0.93 \pm 0.08 \mathrm{~b}$ \\
& $\mathrm{C} 16$ & $8.85 \pm 1.22 \mathrm{ab}$ & $2.13 \pm 0.69 \mathrm{ab}$ \\
& $\mathrm{C} 9$ & $4.65 \pm 1.61 \mathrm{~b}$ & $4.36 \pm 1.51 \mathrm{a}$ \\
\hline
\end{tabular}

2,4-D $=2,4$ dichlorophenoxyacetic acid; $2,4,5-\mathrm{T}=2,4,5$ trichlorophenoxyacetic acid; 3,4-D $=3,4$ dichlorophenoxyacetic acid; $\mathrm{BAP}=$ benzylaminopurine; Kin $=$ kinetin .

Values are mean \pm SE. Mean values in each column of explant followed by the same letter do not differ statistically at $P<0.05$ according to Duncan's test.

Table 5. Effects of combination auxin cytokinin on average of embryogenic calli induction from petals and staminodes in four cocoa genotypes.

\begin{tabular}{|c|c|c|c|}
\hline \multirow[b]{2}{*}{ Genotype } & \multirow{2}{*}{$\begin{array}{l}\text { Auxin/cytokinin combination } \\
\text { in induction medium }\end{array}$} & \multicolumn{2}{|c|}{ Avg percentage of embryogenic calli } \\
\hline & & Petals & Staminodes \\
\hline \multirow[t]{12}{*}{$\mathrm{C} 1$} & $2,4-\mathrm{D} / 0.25 \mathrm{mg} \cdot \mathrm{L}^{-1} \mathrm{BAP}$ & $12.22 \mathrm{ce}$ & $0 \mathrm{e}$ \\
\hline & $2,4-\mathrm{D} / 0.25 \mathrm{mg} \cdot \mathrm{L}^{-1} \mathrm{Kin}$ & $22.59 \mathrm{bd}$ & $0 \mathrm{e}$ \\
\hline & $2,4-\mathrm{D} / 0.5 \mathrm{mg} \cdot \mathrm{L}^{-1} \mathrm{BAP}$ & $6.67 \mathrm{de}$ & $0 \mathrm{e}$ \\
\hline & $2,4-\mathrm{D} / 0.5 \mathrm{mg} \cdot \mathrm{L}^{-1} \mathrm{Kin}$ & $35.12 \mathrm{~b}$ & $1.92 \mathrm{de}$ \\
\hline & $2,4,5-\mathrm{T} / 0.25 \mathrm{mg} \cdot \mathrm{L}^{-1} \mathrm{BAP}$ & $6.36 \mathrm{de}$ & $0 \mathrm{e}$ \\
\hline & $2,4,5-\mathrm{T} / 0.25 \mathrm{mg} \cdot \mathrm{L}^{-1} \mathrm{Kin}$ & $63.37 \mathrm{a}$ & $20.00 \mathrm{a}$ \\
\hline & $2,4,5-\mathrm{T} / 0.5 \mathrm{mg} \cdot \mathrm{L}^{-1} \mathrm{Kin}$ & $28.89 \mathrm{bc}$ & $6.67 \mathrm{c}$ \\
\hline & $3,4-\mathrm{D} / 0.25 \mathrm{mg} \cdot \mathrm{L}^{-1} \mathrm{BAP}$ & $5.00 \mathrm{ef}$ & $0 \mathrm{e}$ \\
\hline & $3,4-\mathrm{D} / 0.25 \mathrm{mg} \cdot \mathrm{L}^{-1} \mathrm{Kin}$ & $22.70 \mathrm{bc}$ & $0 \mathrm{e}$ \\
\hline & $3,4-\mathrm{D} / 0.5 \mathrm{mg} \cdot \mathrm{L}^{-1} \mathrm{Kin}$ & $10.82 \mathrm{ce}$ & $0 \mathrm{e}$ \\
\hline & $\mathrm{Pic} / 0.25 \mathrm{mg} \cdot \mathrm{L}^{-1} \mathrm{Kin}$ & $6.67 \mathrm{de}$ & $0 \mathrm{e}$ \\
\hline & $\mathrm{Pic} / 0.5 \mathrm{mg} \cdot \mathrm{L}^{-1} \mathrm{BAP}$ & $0 \mathrm{f}$ & $11.11 \mathrm{ab}$ \\
\hline \multirow[t]{5}{*}{$\mathrm{C} 14$} & $2,4-\mathrm{D} / 0.25 \mathrm{mg} \cdot \mathrm{L}^{-1} \mathrm{Kin}$ & $2.22 \mathrm{ef}$ & $0 \mathrm{e}$ \\
\hline & $2,4,5-\mathrm{T} / 0.25 \mathrm{mg} \cdot \mathrm{L}^{-1} \mathrm{BAP}$ & $16.20 \mathrm{bc}$ & $9.21 \mathrm{bc}$ \\
\hline & $2,4,5-\mathrm{T} / 0.5 \mathrm{mg} \cdot \mathrm{L}^{-1} \mathrm{Kin}$ & $7.41 \mathrm{de}$ & $6.67 \mathrm{c}$ \\
\hline & $3,4-\mathrm{D} / 0.25 \mathrm{mg} \cdot \mathrm{L}^{-1} \mathrm{BAP}$ & $4.76 \mathrm{ef}$ & $0 \mathrm{e}$ \\
\hline & $3,4-\mathrm{D} / 0.25 \mathrm{mg} \cdot \mathrm{L}^{-1} \mathrm{Kin}$ & $11.43 \mathrm{~cd}$ & $0 \mathrm{e}$ \\
\hline \multirow[t]{6}{*}{$\mathrm{C} 16$} & $2,4-\mathrm{D} / 0.25 \mathrm{mg} \cdot \mathrm{L}^{-1} \mathrm{BAP}$ & $22.02 \mathrm{bc}$ & $0 \mathrm{e}$ \\
\hline & 2,4-D/0.25 mg. $\mathrm{L}^{-1} \mathrm{Kin}$ & $10.37 \mathrm{ce}$ & $13.33 \mathrm{bc}$ \\
\hline & $2,4-\mathrm{D} / 0.5 \mathrm{mg} \cdot \mathrm{L}^{-1} \mathrm{Kin}$ & $32.12 \mathrm{~b}$ & $0 \mathrm{e}$ \\
\hline & $2,4,5-\mathrm{T} / 0.25 \mathrm{mg} \cdot \mathrm{L}^{-1} \mathrm{Kin}$ & $36.67 \mathrm{~b}$ & $12.86 \mathrm{bc}$ \\
\hline & $2,4,5-\mathrm{T} / 0.5 \mathrm{mg} \cdot \mathrm{L}^{-1} \mathrm{Kin}$ & $6.67 \mathrm{de}$ & $0 \mathrm{e}$ \\
\hline & $\mathrm{Pic} / 0.5 \mathrm{mg} \cdot \mathrm{L}^{-1} \mathrm{Kin}$ & $36.67 \mathrm{~b}$ & $7.87 \mathrm{c}$ \\
\hline \multirow[t]{9}{*}{ C9 } & $2,4-\mathrm{D} / 0.25 \mathrm{mg} \cdot \mathrm{L}^{-1} \mathrm{BAP}$ & $10.37 \mathrm{ce}$ & $12.79 \mathrm{bc}$ \\
\hline & $2,4-\mathrm{D} / 0.25 \mathrm{mg} \cdot \mathrm{L}^{-1} \mathrm{Kin}$ & $8.89 \mathrm{de}$ & $0 \mathrm{~d}$ \\
\hline & $2,4-\mathrm{D} / 0.5 \mathrm{mg} \cdot \mathrm{L}^{-1} \mathrm{BAP}$ & $13.97 \mathrm{~cd}$ & $15.02 \mathrm{~b}$ \\
\hline & $2,4-\mathrm{D} / 0.5 \mathrm{mg} \cdot \mathrm{L}^{-1} \mathrm{Kin}$ & $11.43 \mathrm{~cd}$ & $10.32 \mathrm{bc}$ \\
\hline & $2,4,5-\mathrm{T} / 0.5 \mathrm{mg} \cdot \mathrm{L}^{-1} \mathrm{Kin}$ & $0 \mathrm{f}$ & $2.38 \mathrm{de}$ \\
\hline & $3,4-\mathrm{D} / 0.25 \mathrm{mg} \cdot \mathrm{L}^{-1} \mathrm{BAP}$ & $2.22 \mathrm{ef}$ & $17.78 \mathrm{~b}$ \\
\hline & $3,4-\mathrm{D} / 0.25 \mathrm{mg} \cdot \mathrm{L}^{-1} \mathrm{Kin}$ & $11.75 \mathrm{~cd}$ & $7.14 \mathrm{c}$ \\
\hline & $3,4-\mathrm{D} / 0.5 \mathrm{mg} \cdot \mathrm{L}^{-1} \mathrm{BAP}$ & $6.67 \mathrm{de}$ & $0 \mathrm{e}$ \\
\hline & $\mathrm{Pic} / 0.25 \mathrm{mg} \cdot \mathrm{L}^{-1} \mathrm{Kin}$ & $4.44 \mathrm{ef}$ & $0 \mathrm{e}$ \\
\hline
\end{tabular}

$\mathrm{BAP}=$ benzylaminopurine; Kin $=$ kinetin .

Mean values in each column followed by the same letter do not differ statistically at $P<0.05$ according to Duncan test.

Zero response with both petals and staminodes are not indicated in the table.

from 2,4-D, 2,4,5-T, and picloram. The induction media supplemented with dicamba produced the lowest percent explants with calli. Petals were found to produce more calli than staminodes in all the genotypes evaluated. For the staminodes, C9 was found to form significantly higher percentage of calli than $\mathrm{C} 1$ (Table 2).

Induction of somatic embryogenic calli. The effect of the different factors on the percentage of embryogenic calli varied according to the explants. With petals, the levels of factors auxin, cytokinin, genotype, and their interactions had significant effect on the induction of embryogenic calli. With staminodes, only genotype and auxin and their interaction with cytokinin had a significant effect (Table 3).

Callogenic petals produced significantly higher embryogenic calli on induction media supplemented with $1 \mathrm{mg} \cdot \mathrm{L}^{-1} 2,4-\mathrm{D}$ and 1 $\mathrm{mg} \cdot \mathrm{L}^{-1} 2,4,5-\mathrm{T}$ in comparison with the other auxins evaluated. On the other hand, calli induced from staminodes formed the lowest percentage of embryogenic cultures. There were no embryo produced on media supplemented with dicamba from the two explants evaluated (Table 4).

For each type of cytokinin, there were no significant differences between the two concentrations $\left(0.25\right.$ or $\left.0.5 \mathrm{mg} \cdot \mathrm{L}^{-1}\right)$ evaluated. Petal explants cultured on media supplemented with Kin produced significantly more embryogenic calli than those produced on BAP. On the other hand, staminodes produced lower embryogenic calli in media supplemented with both the cytokinin evaluated (Table 4).

Petals were found to be the best explants for induction of somatic embryogenesis in $\mathrm{C} 1, \mathrm{C} 14$, and $\mathrm{C} 16$. In $\mathrm{C}$, there was no significant difference between the petals and staminodes. Genotype $\mathrm{C} 1$ exhibited the best mean percent of somatic embryogenesis (Table 4).

Auxins 2,4-D and 2,4,5-T combined with Kin were found to favor the induction of somatic embryogenesis in all genotypes. The petal explants produced the highest embryogenic response for all the genotypes when cultured on media supplemented with the combination of $1 \mathrm{mg} \cdot \mathrm{L}^{-1} 2,4,5-\mathrm{T} / 0.25 \mathrm{mg} \cdot \mathrm{L}^{-1}$ Kin and the second best combination was 1 $\mathrm{mg} \cdot \mathrm{L}^{-1}$ 2,4-D/0.5 $\mathrm{mg} \cdot \mathrm{L}^{-1} \mathrm{Kin}$ (Table 5). It was also observed that picloram and 3,4-D were found to be specific in that they were able to induce somatic embryogenesis in $\mathrm{C} 16$ and $\mathrm{C} 9$, respectively. Figure 2 shows somatic embryos of genotype C16 induced on medium supplemented with $1 \mathrm{mg} \cdot \mathrm{L}^{-1}$ picloram and $0.5 \mathrm{mg} \cdot \mathrm{L}^{-1} \mathrm{Kin}$.

\section{Discussion}

It was observed that 2,4-D and 2,4,5-T had a broad spectrum action on somatic embryogenesis compared with 3,4-D or picloram. The results of the current study are on line with those of López-Baez et al. (2000) who reported that the combinations of 0.25 $\mathrm{mg} \cdot \mathrm{L}^{-1} \mathrm{Kin}$ with $1 \mathrm{mg} \cdot \mathrm{L}^{-1} 2,4-\mathrm{D}$ or $2,4,5-\mathrm{T}$ led to a successful induction somatic embryogenesis in two genotypes (H20 and H31). In the present study, somatic embryos were induced on calli derived from petals with $1 \mathrm{mg} \cdot \mathrm{L}^{-1}$ of picloram. These results are contrary to the work of Zuyasna et al. (2012) who reported that the low concentrations (less than $3 \mathrm{mg} \cdot \mathrm{L}^{-1}$ ) of picloram were not able to induce somatic embryogenesis in north aceh cocoa genotype. A possible explanation could be due to the differences in the genetic make up. It was also observed that the petals produced higher embryogenic cultures than staminodes explants in all the genotypes evaluated. These results are in contrast with those of Zuyasna et al. (2012) who found that staminode explants produced 3 to 10 times more somatic embryos than petals. This could be because the cacao genotypes used by Zuyasna et al. (2012) were different from those evaluated in the current study. Indeed genotype dependent response 


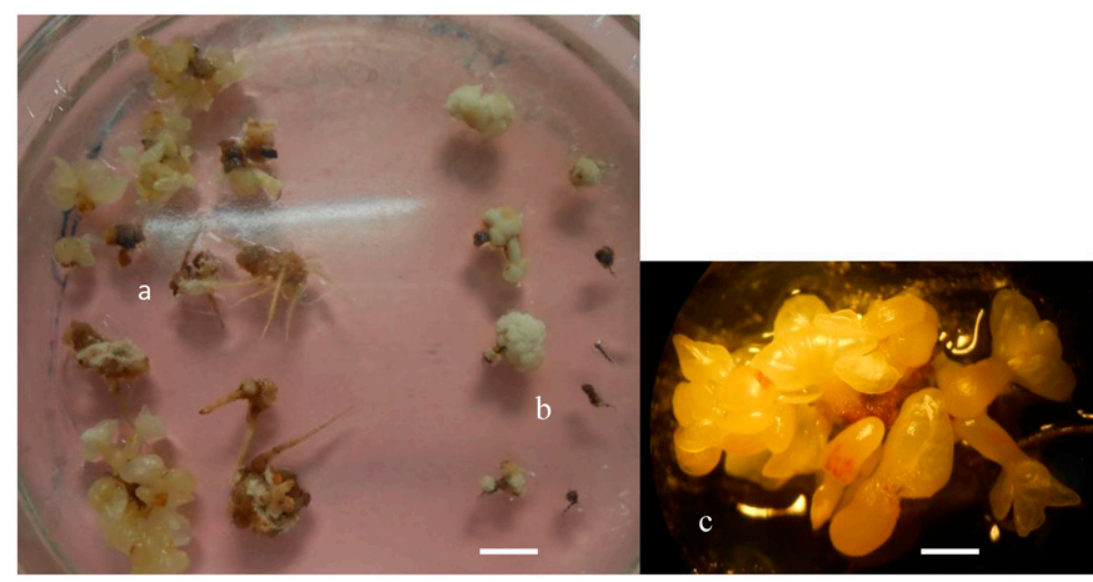

Fig. 2. Embryogenic calli of $\mathrm{C} 16$ from induction medium combining $1 \mathrm{mg} \cdot \mathrm{L}^{-1}$ Picloram and $0.5 \mathrm{mg} \cdot \mathrm{L}^{-1}$ kinetin. (A) Petals and (B) staminodes. (C) Embryos derived from petals 3 months after induction. $\mathrm{Bar}=0.5 \mathrm{~cm}$.

of cacao somatic embryogenesis has been reported previously (Ajijah et al., 2014).

The performance of 3,4 D in C9 was comparable with $2,4-\mathrm{D}$ which is the most used auxin in cocoa somatic embryogenesis. In rubber (Hevea brasiliensis), 3,4-D which is considered as a "weak" auxin was found to give better result compared with 2,4-D when combined with BAP (Michaux-Ferrière and Carron, 1989). An attempt to induce somatic embryogenesis with calli obtained from media supplemented with dicamba was not successful. This may be explained by an inappropriate concentration of auxin (dicamba) or its combination with an inadequate or a suboptimum concentration of cytokinin (Kouassi et al., 2013). In oil palm, the highest haustorium embryos producing embryogenic callus was obtained from primary callus after culture on MS medium supplemented with $1 \mathrm{mg} \cdot \mathrm{L}^{-1}$ dicamba in the presence of $200 \mathrm{mg} \cdot \mathrm{L}^{-1}$ ascorbic acid (Chehmalee and Te-chato, 2008). In the current study, no embryo was produced on induction medium supplemented with dicamba. This is the first report of the use of dicamba and 3,4-D to evaluate callus and somatic embryogenesis induction in cocoa.

In this study, for each type of cytokinin, there were no significant differences between the two concentrations evaluated. It is therefore recommended to use the lowest concentration to induce somatic embryogenesis. Petals were found to be the best explants for induction of somatic embryogenesis in all the genotypes evaluated except in C9 in which both petals and staminodes had similar embryogenic response. The results of the current study concur with those of Ajijah et al. (2016) have reported that Kin in combination with 2,4-D induced higher responses of somatic embryogenesis when basal petals were used compared with staminodes in some genotypes (GC7, ICCRI2, and Cimmangu2). On the contrary, in other genotypes (Sca 6, ICS 13, and DR 2) staminode explants showed better responses than petals. In the present study, it was also observed that for responsive genotypes, induction media supplemented with Kin were more embryogenic than that with BAP. However, for less responsive genotype, Kin could have the same effect as BAP.

\section{Conclusion}

Auxins 2,4,5-T and 2,4-D in combination with Kin were observed to have a broad spectrum action on somatic embryogenesis induction. It was also demonstrated for the first time ever that it is possible to use picloram and 3,4-D to induce callus and somatic embryogenesis respectively in the elite cocoa genotypes. However, it is necessary to evaluate the quality of somatic embryos regenerated using the two cytokinins.

\section{Literature Cited}

Ajijah, N., R.S. Hartati, R. Rubiyo, D. Sukma, and S. Sudarsono. 2016. Effective cacao somatic embryo regeneration on kinetin supplemented DKW medium and somaclonal variation assessment using SSRS markers. Agrivita 38(1):80-92.

Ajijah, N., Rubiyo, and Sudarsono. 2014. Callogenesis and somatic embryogenesis of cacao using thidiazuron through one step of callus induction (in Indonesian). J. Penelitian Pertanian Tanaman Industri 20(4):179-186. <http://www. ejurnal.litbang.pertanian.go.id/index.php/jptip/ article/view/2580/2220>.

Chehmalee, S. and S. Te-chato. 2008. Induction of somatic embryogenesis and plantlet regeneration from cultured zygotic embryo of oil palm. J. Agr. Tech. 4(2):137-146.

Conseil Café Cacao. 2014. Programme QuantitéQualité-Croissance "2QC » 2014-2023. Le Conseil de Régulation, de Stabilisation et de
Développement de la filière café-cacao. Dec. 2016. <www.conseilcafecacao.ci/docs/Programme 2Qc_2014-2023.pdfs

Driver, J.A. and A.H. Kuniyuki. 1984. In vitro propagation of Paradox walnut rootstock. HortScience 19:507-509.

Dudits, D., J. Györgyey, L. Bögre, and L. Bakó 1995. Molecular biology of somatic embryogenesis, p. 267-308. In: T. A. Thorpe (ed.) In Vitro Embryogenesis in Plants. Kluwer Academic Publishers, Dordrecht.

Guiltinan, M.J. and S. Maximova. 2000. Recent advances in the tissue culture of cocoa from somatic embryos to bentwood gardens: A short review. In Abstr. Ingenic Workshop on the New Technologies and Cocoa Breeding, Kota Kinabalu, Malaysia.

International Cocoa Organization (ICCO). 2012. How many smallholders are there worldwide producing cocoa? What proportion of cocoa worldwide is produced by smallholders? Aug. 2016. <http://www.icco.org/faq/57-cocoa-production/ 123-how-manysmallholders-are-there-worldwideproducing-cocoa-what-proportion-of-cocoaworldwide-isproduced-by-smallholders.html >.

Kouassi, K.M., K.E. Koffi, N.G. Konkon, M. Gnagne, M. Koné, and T.H. Kouakou. 2013. Influence of plant growth regulators on somatic embryogenesis induction from inner teguments of rubber (Hevea brasiliensis) seeds. Afr. J. Biotechnol. 12(16):1972-1977.

Li, Z., A. Traoré, S.N. Maximova, and M.J. Guiltinan. 1998. Somatic embryogenesis and plant regeneration from floral explants of cocoa (Theobroma cacao L.) using Thidiazuron. In Vitro Cell. Dev. Biol. 34:293-299.

López-Baez, O., J.L. Moreno-Martmnez, and S. Pacheco-Rodas. 2000. Advances in cocoa Theobroma cacao propagation by somatic embryogenesis in Mexico. In Abstr. 3' Ingenic Workshop on the New Technologies and Cocoa Breeding, Kota Kinabalu, Malaysia.

Maximova, S.N., L. Alemano, A. Youg, A. Traoré, N. Ferrier, and M.J. Gultinan. 2002. Genotype variability, efficiency and cellular origin of primary and secondary somatic embryogenesis of Theobroma cacao L. the chocolate tree. In Vitro Cell. Dev. Biol. 38:252-259.

Michaux-Ferrière, N. and M.P. Carron. 1989. Histology of early somatic embryogenesis in Hevea brasiliensis. The importance of timing of subculturing. Plant Cell Tissue Organ Cult. 19:243-256.

Murashige, T. and F. Skoog. 1962. A revised medium for rapid growth and bioassays with tobacco tissue cultures. Physiol. Plant. 15:473497.

Traore, A. and M. Guiltinan. 2006. Effects of carbon source and explants type on somatic embryogenesis of four cacao genotypes. HortScience 41:753-758.

Zuyasna, S. Hafsah, R. Fajri, O.M. Syahputra, and G. Ramadhan. 2012. The effect of picloram concentrations and explants types on the induction of somatic embryo on North Aceh Cocoa genotype. Poster, Proc. 2nd Annu. Int. Conf. Syiah Kuala Univ. 2012 and The 8th IMT-GT Uninet Biosc. Conf. Banda Aceh, Vol. 2 Number 1. 